The Open Biomedical Engineering
Jentham OPEN CrossMark
Content list available at: www.benthamopen.com/TOBEJ/

\title{
CORRIGENDUM
}

\section{Reliability, Learnability and Efficiency of Two Tools for Cement Crowns Retrieval in Dentistry}

Cristina Bignardi ${ }^{1, *}$, Elisabetta M. Zanetti ${ }^{2}$, Mara Terzini ${ }^{1}$, Anna R. Ciccola ${ }^{1}$, Gianmario Schierano ${ }^{3}$ and Alberto L. Audenino ${ }^{1}$

${ }^{I}$ Department of Mechanical and Aerospace Engineering, Polytechnic University of Turin, Turin, Italy

${ }^{2}$ Department of Engineering, University of Perugia, Perugia, Italy

${ }^{3}$ Department of Surgical Science, Dental School, C.I.R University of Turin, Turin, Italy

Reliability, Learnability and Efficiency of Two Tools for Cement Crowns Retrieval in Dentistry

The Open Biomedical Engineering Journal, 2018, 12: 27-35

The correct spelling of word Department in second affiliation is mentioned below:

Department of Engineering, University of Perugia, Perugia, Italy

The original spelling of word Department provided was:

Departiment of Engineering, University of Perugia, Perugia, Italy

\section{(C) 2018 Bignardi et al.}

This is an open access article distributed under the terms of the Creative Commons Attribution 4.0 International Public License (CC-BY 4.0), a copy of which is available at: https://creativecommons.org/licenses/by/4.0/legalcode. This license permits unrestricted use, distribution, and reproduction in any medium, provided the original author and source are credited. 